\title{
Commentary
}

\section{Biosimilar Interchangeability and Emerging Treatment Strategies for Inflammatory Bowel Diseases: A Commentary}

\author{
Richard H. Parrish II (D) \\ Department of Biomedical Sciences, Mercer University School of Medicine, Columbus, GA 31209, USA; \\ parrish_rh@mercer.edu; Tel.: +1-(706)-321-7218
}

check for

updates

Citation: Parrish, R.H., II Biosimilar Interchangeability and Emerging

Treatment Strategies for

Inflammatory Bowel Diseases: A Commentary. Gastroenterol. Insights 2021, 12, 293-301. https://doi.org/ 10.3390 /gastroent 12030026

Academic Editors: Gaetano Luglio and Alessandro Granito

Received: 7 May 2021

Accepted: 21 June 2021

Published: 24 June 2021

Publisher's Note: MDPI stays neutral with regard to jurisdictional claims in published maps and institutional affiliations.

Copyright: (C) 2021 by the author. Licensee MDPI, Basel, Switzerland. This article is an open access article distributed under the terms and conditions of the Creative Commons Attribution (CC BY) license (https:// creativecommons.org/licenses/by/ $4.0 /)$.

\begin{abstract}
This commentary summarizes a collection of key references published within the last ten years, and identifies pharmacologic research directions to improve treatment access and success through greater biosimilar or "follow-on" biologic utilization combined with other targeted small molecule agents that possess unique pathophysiologic mechanisms for inflammatory bowel diseases (IBD) in adult and pediatric patients. Since they are not identical to the originator or reference biologic agent, all biosimilars are not generically equivalent. However, in the US and other countries, they are considered therapeutically interchangeable if the manufacturer has demonstrated no clinically meaningful differences from the reference product. Comparisons of different clinical initiation and switching scenarios are discussed with reference to interchangeability, immunogenicity, nocebo effect, cost effectiveness, and time courses for discontinuation rates.
\end{abstract}

Keywords: antibody; biologic; biosimilar; Crohn disease; guideline; inflammatory bowel disease; molecule; small; monitoring; monoclonal; nocebo; pediatric; switching; drug; ulcerative colitis

\section{Introduction}

The most commonly used reference anti-TNF- $\alpha$ biologic products for moderate to severe Crohn Disease (CD) and ulcerative colitis (UC) include adalimumab and infliximab with several biosimilars on the market or in development including adalimumab-adaz, -adbm, -afzb, -atto, -bwwd, and -fkjp; and infliximab-dyyb, -abda, -axxq, and -qbtx, respectively. Three biosimilars for infliximab have been marketed in the US in the past five years. Six biosimilars for adalimumab have been approved for marketing since 2016, and are expected to be marketed somewhere in the world in 2023 [1]. No biosimilar products currently exist for the anti-integrins, vedolizumab and natalizumab, or for the anti-interleukin $12 / 23$, ustekinumab, although clinical trials are underway both for other biologics within the class and biosimilars to these reference products $[2,3]$.

While guidelines have been developed for the treatment of CD and UC populations, questions remain regarding the appropriate selection, monitoring, and switching rules for both biologic and biosimilar use in individual patients [4-7]. Based on disease severity at initial presentation, patients are started often on a biologic or combinations of biologics (i.e., agents with different mechanisms of action, such as combining an anti-TNF- $\alpha$ and an anti-integrin or anti-IL 12/23) instead of steroids and immunomodulators, especially in children [8-11]. In fact, higher rates of morbidity and mortality have been observed in patients treated with prolonged steroids compared to biologics [12]. Because of the expense of biologics and their negative cost-benefit calculations compared to surgical intervention, biosimilars have been touted to improve patient access through a reduction in the clinical, economic, and humanistic costs of treatment [13-15]. Moreover, because treatment success with anti-TNF- $\alpha$-based ranges from 33 to $50 \%$ in the long term, research to increase the array of pharmacotherapy choices, including re-purposing existing anti-inflammatory agents, is ongoing. This commentary reviews key citations published within the last ten years, and identifies pharmacologic research directions for the improved utilization of biosimilars and other potential combination targeted non-biologic therapies. 


\section{Switching to Biosimilars}

While there is ample evidence to assert that biosimilars for infliximab and adalimumab are comparable to the reference product in moderate to severe IBD [8,16-39], there are no head-to-head comparisons between them. This lack of scientific evidence has caused some to question whether it is appropriate to extrapolate the indications for the reference product to the biosimilar, and concerns related to reverse signaling, induction of regulatory macrophages, and antibody-dependent cellular cytotoxicity have been raised in addition to pharmacokinetic differences, especially with respect to systemic clearance [40-43]. While clinical response rates in the short and long-term have been shown to be comparable, switching patients to biosimilars needs to be individualized and programmatic [7]. In the case of infliximab-dyyb, two efficacy trials and three clinical trials were conducted in rheumatoid patients and summarized in a recent report. The efficacy trials showed no significant differences in the relevant functional characteristics or in the adverse event profiles. The clinical trials displayed no differences in Cmax or the area under the curve (AUC). These results allowed US regulators to extrapolate data to support indications expanded into IBD [44]. Efforts to optimize therapy for preserving colonic integrity using combinations of agents, many of which will act topically within the bowel lumen, will drive future research programs.

There are three scenarios where switching medications occur: (1) biosimilar instead of biologic in treatment-naïve patients; (2) biologic to biosimilar switch; and (3) biosimilar to biologic in the same class $[8,34-39,45]$. There is evidence of a slow uptake of biosimilar use due to lack of third-party insurance coverage for multiple reasons (including contractual reference product rebates to pharmacy benefit managers), patent disputes in court related to approved indications, and reference product manufacturer market strategies which limit use [46,47]. According to the Biosimilars Council, a division of the Association for Accessible Medicines, the use of biosimilars could result in \$54B USD savings over the next 10 years, and improve access to biosimilars for an additional $1.2 \mathrm{M}$ patients in the US alone [48]. Table 1 summarizes biosimilars that have been approved for use in the US by the Food and Drug Administration.

Table 1. Biosimilars approved and launched in the US for CD and UC.

\begin{tabular}{|c|c|c|c|}
\hline Reference Biologic & Biosimilar & Approved & Launched \\
\hline \multirow[t]{2}{*}{ Enbrel (etanercept) } & Erelzi (etanercept-szzs) & August 2016 & \\
\hline & Eticovo (etanercept-ykro) & April 2019 & \\
\hline \multirow[t]{6}{*}{ Humira (adalimumab) } & Amjevita (adalimumab-atto) & September 2016 & \\
\hline & Cyltezo (adalimumab-adbm) & September 2016 & \\
\hline & Hyrimoz (adalimumab-adaz) & October 2018 & \\
\hline & Hadlima (adalimumab-bwwd) & July 2019 & \\
\hline & Abrilada (adalimumab-afzb) & November 2019 & \\
\hline & Hulio (adalimumab-fkjp) & July 2020 & \\
\hline \multirow[t]{4}{*}{ Remicade (infliximab) } & Inflectra (infliximab-dyyb) & April 2016 & November 2016 \\
\hline & Renflexis (infliximab-abda) & April 2017 & July 2017 \\
\hline & Ixifi (infliximab-qbtx) & December 2017 & \\
\hline & Avsola (infliximab-axxq) & December 2019 & \\
\hline
\end{tabular}

\section{Combining Biosimilars with Non-Biologic Small Molecules}

Combinations of anti-TNF- $\alpha$ biosimilars with anti-adhesion, anti-integrin, and interleukin 12/23 antagonists (more common in children than in adults) as well as Janus kinase inhibitors (tofacitinib, peficitinib, upadacitinib, filgotinib), sphingosine-1-phosphate [S1P] receptor modulators (ozanimod, etrasimod), phosphodiesterase-4 inhibitors (apremilast), selective histone deacetylase 3 inhibitors (givinostat, vorinostat) and/or substitutions of phosphatidylcholine (LT-02) (i.e., agents with different mechanisms of action) are on research agendas in various phases and treatment horizons [49-56]. Brief research reports on the use of small molecules and combinations with either the reference product or the 
biosimilar for potential treatment are nascent and based only on clinical experience. Therapy may be optimized through personalized approaches based on disease severity, lesion location, and phenotypes in addition to the use of therapeutic and clinical targets [57-59]. Future research should quantify the relative contribution of each of these choices to overall treatment success, as a recent economic study suggests that tofacitinib may be more cost-effective than any injectable biologic [60]. Table 2 summarizes the non-biological small molecules under current investigation for CD and UC.

Table 2. Non-biological agents with potential for therapeutic use in CD and UC.

\begin{tabular}{cc}
\hline Therapeutic Class or Mechanism of Action & Investigational Agent \\
\hline & Tofacitinib \\
Janus kinase (JAK) inhibitors & Peficitinib \\
& Upadacitinib \\
Sphingosine-1-phosphate (S1P) receptor modulators & Ozanimod \\
Phosphodiesterase 4 (PDE-4) inhibitors & Etrasimod \\
Histone deacetylase (HDAC) inhibitors & Apremilast \\
Mucoprotective substitutions of phosphatidylcholine & Ginvinostat \\
& Vorinostat \\
\end{tabular}

Many of these newer non-biologic therapies are under investigation, primarily in adults with IBD, and several (tofacitinib, upadacitinib, ozanimod, apremilast, vorinostat) have been approved for other indications for them. While approved recently in the European Union and Japan, the US FDA has rejected filgotinib's application for use in adult rheumatoid arthritis, citing concerns about the overall risk-to-benefit profile at the $200 \mathrm{mg}$ dose. However, with the increasing prevalence of $C D$ and UC in children, coupled with the up to $50 \%$ durability of remission, studies which validate safety and effectiveness of non-biologics in pediatric IBD populations are needed. In addition to solid oral dosage forms, oral liquid formulations appropriate for pediatrics are in development or are on the market. For example, tofacitinib is available in a mass-produced $1 \mathrm{mg} / \mathrm{mL}$ oral liquid, and is indicated in children two years and older for juvenile rheumatoid arthritis [61]. Givinostat received rare pediatric disease designation for Duchenne muscular dystrophy, and the manufacturer has included a $10 \mathrm{mg} / \mathrm{mL}$ oral suspension formulation into the clinical protocol. A vorinostat $50 \mathrm{mg} / \mathrm{mL}$ compounded oral suspension has been reported in the literature based on a Children's Oncology Group report for use in refractory solid tumors [62]. While none of these non-biologics have a labeled pediatric indication for either CD or UC currently, manufacturers would be prudent to include pediatric-friendly dosage forms, such as oral liquids, minitablets, and orally-disintegrating tablets, in future product submissions.

\section{Psychosocial Aspects and the Nocebo Effect}

Most guidelines agree that it is important to assess mental health disorders and stress, not as contributors to IBD etiology, but as influencers of its course [63]. The gutbrain connection between enhanced intestinal autophagy and psychosocial stress has been posited to modulate gut microbiota and inflammation [64]. Although psychosocial factors such as anxiety, depression, and perceived stress appear to play a significant role in IBD pain [65], mental illness often precedes the development of IBD [66-68]. Moreover, non-psychiatric morbidities, as well as significant physical trauma experienced early in life, can increase the risk of behavioral comorbidities in IBD. The early recognition and treatment of depression and other psychosocial burdens through enhancing self-efficacy and locus of control within integrated multidisciplinary care pathways is essential, and is likely to improve the overall health and wellbeing of patients in the general course of IBD [69]. While a number of pharmacologic agents, such as selective serotonin reuptake inhibitors, tricyclic anti-depressants, and neuromodulators, have been employed to reduce 
psychological stress, studies of these agents in IBD are lacking. Multidisciplinary care teams which address the biopsychosocial impacts of IBD on patients' lives seem to provide better results to improve patient care and quality of life [70].

One prominent non-pharmacological effect seen in patients that are candidates for a switch from a reference product to a biosimilar is the so-called "nocebo effect" [71-74]. This effect has been observed in adult and pediatric patients and their parents/caregivers, and the response may be more pronounced in patients who do not want to switch to the biosimilar. To minimize this effect, healthcare provider-patient communication should be based mainly on the clarification of what biosimilarity means, and should stress the data on efficacy and safety of biosimilar drugs rather than expense reduction.

The nocebo effect may have an important impact on an increased discontinuation rate after switching in the absence of patient symptomatology [73,75]. Real-world studies of anti-TNF- $\alpha$ agents show higher discontinuation rates in patients switched to biosimilars for non-medical reasons than in historical cohorts maintained on innovators $[8,71,76]$. In addition, there is evidence that the naming convention for biosimilars affects patients perception of interchangeability. The four-letter suffix attached to the reference product name, unique to the US market, differentiates the biosimilar. Now, this practice has been applied to all new biologics [77] which may further confuse the issue for providers and patients alike.

\section{Additional Considerations for Pediatric Patients}

The prevalence of pediatric-onset IBD has risen in the past two decades, and most patients with moderate to severe IBD will require dose escalation within the first year of treatment [78]. Consensus-based guidelines suggest that in children previously naïve to anti-TNF- $\alpha$ agents, either infliximab or adalimumab can be initiated as a "top-down" strategy in CD and for steroid-dependency or chronic disease activity in UC. Infliximab dose escalation (i.e., to $10 \mathrm{mg} / \mathrm{kg}$ or interval shortening to every 6 weeks) and switching to adalimumab or golimumab have been suggested in those with a loss of response or intolerance. Several recent observational studies in pediatric patients confirmed the results of randomized trials conducted in adult populations (that is, there were no differences in the pharmacokinetic, immunogenic, safety, or effectiveness when switching children with IBD) $[23,79,80]$. Combination with immunomodulators and/or other biologics may lower the risk of antibody formation [81]. As mentioned earlier, oral liquid formulations containing child-appropriate excipients and vehicles need to be a part of the research and development for small molecule non-biologic agents.

Developmental delays in the attainment of age-appropriate weight and height affects between $40-60 \%$ of children with IBD, with weight loss, reduced bone mineral density, and delayed onset of puberty as the most important concerns [82]. Vitamin D3 deficiency and osteoporosis may occur in over $75 \%$ and $25 \%$ of patients, respectively, and decreased levels of insulin-like growth factor and testosterone are seen as disease severity progresses [83]. Used for many years to reduce bone turnover in childhood cancer, trials of zoledronic acid infusions and, to some degree, denosumab, are ongoing to validate their effectiveness in addressing secondary osteoporosis precipitated by chronic steroid use and malnutrition in these children $[84,85]$.

\section{Summary}

Biosimilar development and utilization, as well as non-biologic oral agents with unique pathological targets, will continue to dominate efforts to improve patient access and reduce the overall cost of care as non-surgical treatments for CD and UC in adults and children. Therapeutic drug monitoring, combined with inflammatory biomarkers, have become the standard of care to assess effectiveness. New combinations of agents with different mechanisms of action, in addition to immunomodulators, will drive regimen optimization (especially those acting locally within the bowel lumen). Future research should quantify the relative contribution of each of these choices to overall treatment 
success. Patient and provider education and positive framing of non-medical switching strategies needs to be incorporated into organized programs for both adult and pediatric populations, including parents and caregivers, so that the negative attribution towards biosimilar initiation or switching is minimized. Psychosocial issues often impact the development and progress of IBD, and are best approached through a multidisciplinary approach. Early attention to growth and development in children is paramount to optimal physical and psychological well-being. Research to elucidate pharmacotherapies of choice for anxiety, depression, and pain is needed in children and adults. The development of non-biologic small molecules that can be absorbed orally or affect the colonic lumen topically will be vital for the achievement of sustained clinical remission in adults and children. Oral liquid formulations for children and those that cannot swallow oral solids is important for continued success in treating vulnerable patient populations.

Funding: This research received no external funding.

Institutional Review Board Statement: Not applicable.

Informed Consent Statement: Not applicable.

Conflicts of Interest: The author declares no conflict of interest.

\section{References}

1. Managing Costs and Care with Biosimilars. Available online: https://www.cardinalhealth.com/content/dam/corp/web/ documents / data-sheet/cardinal-health-biosimilars-chart.pdf (accessed on 19 April 2021).

2. Vedolizumab Biosimilar-Research Grade [ICH4035]-ichorbio. Available online: https://ichor.bio/product/vedolizumabbiosimilar-research-grade-ich4035/ (accessed on 28 April 2021).

3. SAMSUNG BIOEPIS Initiates Phase 1 Clinical Trial for SB17, Proposed Biosimilar to Stelara (Ustekinumab). Available online: https:/ / www.samsungbioepis.com/en/newsroom/newsroomView.do?idx=221\&currentPage=1 (accessed on 28 April 2021).

4. Moss, A.C. Optimizing the use of biological therapy in patients with inflammatory bowel disease. Gastroenterol. Rep. 2015, 3, 63-68. [CrossRef]

5. Ooi, C.J.; Hilmi, I.; Banerjee, R.; Chuah, S.W.; Ng, S.C.; Wei, S.C.; Makharia, G.K.; Pisespongsa, P.; Chen, M.H.; Ran, Z.H.; et al. Asia-Pacific Association of Gastroenterology (APAGE) Working Group on Inflammatory Bowel Disease and Asian Organization for Crohn's and Colitis. Best practices on immunomodulators and biologic agents for ulcerative colitis and Crohn's disease in Asia. J. Gastroenterol. Hepatol. 2019, 34, 1296-1315. [CrossRef]

6. Walsh, A.J.; Bryant, R.V.; Travis, S.P.L. Current best practice for disease activity assessment in IBD. Nat. Rev. Gastroenterol. Hepatol. 2016, 13, 567-579. [CrossRef]

7. Steenholdt, C.; Brynskov, J.; Thomsen, O.Ø.; Munck, L.K.; Fallingborg, J.; Christensen, L.A.; Pedersen, G.; Kjeldsen, J.; Jacobsen, B.A.; Oxholm, A.S.; et al. Individualised therapy is more cost-effective than dose intensification in patients with Crohn's disease who lose response to anti-TNF treatment: A randomised, controlled trial. Gut 2014, 63, 919-927. [CrossRef]

8. Plevris, N.; Jones, G.R.; Jenkinson, P.W.; Lyons, M.; Chuah, C.S.; Merchant, L.M.; Pattenden, R.J.; Watson, E.F.; Ho, G.T.; Noble, C.L.; et al. Implementation of CT-P13 via a Managed Switch Programme in Crohn's Disease: 12-Month Real-World Outcomes. Dig. Dis. Sci. 2019, 64, 1660-1667. [CrossRef] [PubMed]

9. Berg, D.R.; Colombel, J.F.; Ungaro, R. The role of early biologic therapy in inflammatory bowel disease. Inflamm. Bowel Dis. 2019, 25, 1896-1905. [CrossRef] [PubMed]

10. Olbjørn, C.; Rove, J.B.; Jahnsen, J. Combination of Biological Agents in Moderate to Severe Pediatric Inflammatory Bowel Disease: A Case Series and Review of the Literature. Pediatr. Drugs 2020, 22, 409-416. [CrossRef] [PubMed]

11. Tarnok, A.; Kiss, Z.; Kadenczki, O.; Veres, G. Characteristics of biological therapy in pediatric patients with Crohn's disease. Expert Opin. Biol. Ther. 2019, 19, 181-196. [CrossRef]

12. Lewis, J.D.; Scott, F.I.; Brensinger, C.M.; Roy, J.A.; Osterman, M.T.; Mamtani, R.; Bewtra, M.; Chen, L.; Yun, H.; Xie, F.; et al. Increased Mortality Rates with Prolonged Corticosteroid Therapy When Compared with Antitumor Necrosis Factor- $\alpha$-Directed Therapy for Inflammatory Bowel Disease. Am. J. Gastroenterol. 2018, 13. [CrossRef]

13. Jacobs, I.; Petersel, D.; Isakov, L.; Lula, S.; Lea Sewell, K. Biosimilars for the Treatment of Chronic Inflammatory Diseases: A Systematic Review of Published Evidence. BioDrugs 2017, 34, 1296-1315. [CrossRef]

14. Archer, R.; Tappenden, P.; Ren, S.; Martyn-St James, M.; Harvey, R.; Basarir, H.; Stevens, J.; Carroll, C.; Cantrell, A.; Lobo, A.; et al. Infliximab, adalimumab and golimumab for treating moderately to severely active ulcerative colitis after the failure of conventional therapy (Including a review of TA140 and TA262): Clinical effectiveness systematic review and economic model. Health Technol. Assess. 2016, 20, 39. [CrossRef]

15. Pillai, N.; Dusheiko, M.; Burnand, B.; Pittet, V. A systematic review of cost-effectiveness studies comparing conventional, biological and surgical interventions for inflammatory bowel disease. PLoS ONE 2017, 12, 1-22. [CrossRef] [PubMed] 
16. Roblin, X.; Rinaudo, M.; Del, E.; Phelip, J.M.; Genin, C.; Peyrin-Biroulet, L.; Paul, S. Development of an algorithm incorporating pharmacokinetics of adalimumab in inflammatory bowel diseases. Am. J. Gastroenterol. 2014, 109, 1250-1256. [CrossRef] [PubMed]

17. Yanai, H.; Lichtenstein, L.; Assa, A.; Mazor, Y.; Weiss, B.; Levine, A.; Ron, Y.; Kopylov, U.; Bujanover, Y.; Rosenbach, Y.; et al. Levels of drug and antidrug antibodies are associated with outcome of interventions after loss of response to infliximab or adalimumab. Clin. Gastroenterol. Hepatol. 2015, 13, 522-530.e2. [CrossRef]

18. Sandborn, W.J.; Feagan, B.G.; Marano, C.; Zhang, H.; Strauss, R.; Johanns, J.; Adedokun, O.J.; Guzzo, C.; Colombel, J.F.; Reinisch, W.; et al. PURSUIT-Maintenance Study Group. Subcutaneous golimumab maintains clinical response in patients with moderate-to-severe ulcerative colitis. Gastroenterology 2014, 146, 96-109. [CrossRef]

19. Bortlik, M.; Duricova, D.; Malickova, K.; Machkova, N.; Bouzkova, E.; Hrdlicka, L.; Komarek, A.; Lukas, M. Infliximab trough levels may predict sustained response to infliximab in patients with Crohn's disease. J. Crohn's Colitis 2013, 7, 736-743. [CrossRef] [PubMed]

20. Levesque, B.G.; Greenberg, G.R.; Zou, G.; Sandborn, W.J.; Singh, S.; Hauenstein, S.; Ohrmund, L.; Wong, C.J.; Stitt, L.W.; Shackelton, L.M.; et al. A prospective cohort study to determine the relationship between serum infliximab concentration and efficacy in patients with luminal Crohn's disease. Aliment. Pharm. Ther. 2014, 39, 1126-1135. [CrossRef] [PubMed]

21. Hayes, M.J.; Stein, A.C.; Sakuraba, A. Comparison of efficacy, pharmacokinetics, and immunogenicity between infliximab monoversus combination therapy in ulcerative colitis. J. Gastroenterol. Hepatol. 2014, 29, 1177-1185. [CrossRef] [PubMed]

22. Vande Casteele, N.; Gils, A.; Singh, S.; Ohrmund, L.; Hauenstein, S.; Rutgeerts, P.; Vermeire, S. Antibody Response to Infliximab and its Impact on Pharmacokinetics can be Transient. Am. J. Gastroenterol. 2013, 108, 962-971. [CrossRef] [PubMed]

23. Zitomersky, N.L.; Atkinson, B.J.; Fournier, K.; Mitchell, P.D.; Stern, J.B.; Butler, M.C.; Ashworth, L.; Hauenstein, S.; Heiner, L.; Chuang, E.; et al. Antibodies to infliximab are associated with lower infliximab levels and increased likelihood of surgery in pediatric IBD. Inflamm. Bowel Dis. 2015, 2, 307-314. [CrossRef] [PubMed]

24. Danese, S.; Bonovas, S.; Peyrin-Biroulet, L. Biosimilars in IBD: From theory to practice. Nat. Rev. Gastroenterol. Hepatol. 2017, 14, 22-31. [CrossRef]

25. Keil, R.; Wasserbauer, M.; Zádorová, Z.; Hajer, J.; Drastich, P.; Wohl, P.; Beneš, M.; Bojková, M.; Svoboda, P.; Konečný, M.; et al. Clinical monitoring: Infliximab biosimilar CT-P13 in the treatment of Crohn's disease and ulcerative colitis. Scand. J. Gastroenterol. 2016, 51, 1062-1068. [CrossRef] [PubMed]

26. Farkas, K.; Rutka, M.; Bálint, A.; Nagy, F.; Bor, R.; Milassin, Á.; Szepes, Z.; Molnár, T. Efficacy of the new infliximab biosimilar CT-P13 induction therapy in Crohns disease and ulcerative colitis-experiences from a single center. Expert Opin. Biol. Ther. 2015, 15, 1257-1262. [CrossRef] [PubMed]

27. Fiorino, G.; Manetti, N.; Armuzzi, A.; Orlando, A.; Variola, A.; Bonovas, S.; Bossa, F.; Maconi, G.; D’Incà, R.; Lionetti, P.; et al. PROSIT-BIO Cohort. The PROSIT-BIO Cohort: A Prospective Observational Study of Patients with Inflammatory Bowel Disease Treated with Infliximab Biosimilar. Inflamm. Bowel Dis. 2017, 23, 233-243. [CrossRef]

28. Gecse, K.B.; Lovász, B.D.; Farkas, K.; Banai, J.; Bene, L.; Gasztonyi, B.; Golovics, P.A.; Kristóf, T.; Lakatos, L.; Csontos, Á.A.; et al. Efficacy and safety of the biosimilar infliximab CT-P13 treatment in inflammatory bowel diseases: A prospective, multicentre, nationwide cohort. J. Crohn's Colitis 2020, 10, 133-140. [CrossRef] [PubMed]

29. Jahnsen, J.; Detlie, T.E.; Vatn, S.; Ricanek, P. Biosimilar infliximab (CT-P13) in the treatment of inflammatory bowel disease: A Norwegian observational study. Expert Rev. Gastroenterol. Hepatol. 2015, 9, 45-52. [CrossRef]

30. Jung, Y.S.; Park, D., II; Kim, Y.H.; Lee, J.H.; Seo, P.J.; Cheon, J.H.; Kang, H.W.; Kim, J.W. Efficacy and safety of CT-P13, a biosimilar of infliximab, in patients with inflammatory bowel disease: A retrospective multicenter study. J. Gastroenterol. Hepatol. 2015, 30, 1705-1712. [CrossRef]

31. Kang, Y.S.; Moon, H.H.; Lee, S.E.; Lim, Y.J.; Kang, H.W. Clinical Experience of the Use of CT-P13, a Biosimilar to Infliximab in Patients with Inflammatory Bowel Disease: A Case Series. Dig. Dis. Sci. 2015, 60, 951-956. [CrossRef]

32. Kolar, M.; Duricova, D.; Bortlik, M.; Hruba, V.; Machkova, N.; Mitrova, K.; Malickova, K.; Lukas, M., Jr.; Lukas, M. Infliximab Biosimilar (RemsimaTM) in Therapy of Inflammatory Bowel Diseases Patients: Experience from One Tertiary Inflammatory Bowel Diseases Centre. Dig. Dis. 2017, 35, 91-100. [CrossRef] [PubMed]

33. Komaki, Y.; Yamada, A.; Komaki, F.; Micic, D.; Ido, A.; Sakuraba, A. Systematic review with meta-analysis: The efficacy and safety of CT-P13, a biosimilar of anti-tumour necrosis factor- $\alpha$ agent (infliximab), in inflammatory bowel diseases. Aliment. Pharm. Ther. 2017, 45, 1043-1057. [CrossRef] [PubMed]

34. Cohen, H.P.; Blauvelt, A.; Rifkin, R.M.; Danese, S.; Gokhale, S.B.; Woollett, G. Switching Reference Medicines to Biosimilars: A Systematic Literature Review of Clinical Outcomes. Drugs 2018, 78, 463-478. [CrossRef]

35. Jørgensen, K.K.; Olsen, I.C.; Goll, G.L.; Lorentzen, M.; Bolstad, N.; Haavardsholm, E.A.; Lundin, K.E.A.; Mørk, C.; Jahnsen, J.; Kvien, T. NOR-SWITCH study group. Switching from originator infliximab to biosimilar CT-P13 compared with maintained treatment with originator infliximab (NOR-SWITCH): A 52-week, randomised, double-blind, non-inferiority trial. Lancet 2017, 389, 2304-2316. [CrossRef]

36. Ratnakumaran, R.; To, N.; Gracie, D.J.; Selinger, C.P.; O'Connor, A.; Clark, T.; Carey, N.; Leigh, K.; Bourner, L.; Ford, A.C.; et al. Efficacy and tolerability of initiating, or switching to, infliximab biosimilar CT-P13 in inflammatory bowel disease (IBD): A large single-centre experience. Scand. J. Gastroenterol. 2018, 53, 700-707. [CrossRef] 
37. Schmitz, E.M.H.; Boekema, P.J.; Straathof, J.W.A.; van Renswouw, D.C.; Brunsveld, L.; Scharnhorst, V.; van de Poll, M.E.C.; Broeren, M.A.C.; Derijks, L.J.J. Switching from infliximab innovator to biosimilar in patients with inflammatory bowel disease: A 12-month multicentre observational prospective cohort study. Aliment. Pharm. Ther. 2018, 47, 356-363. [CrossRef] [PubMed]

38. Smits, L.J.T.; Grelack, A.; Derikx, L.A.A.P.; van Esch, A.A.J.; Boshuizen, R.S.; Drenth, J.P.H.; Hoentjen, F. Long-Term Clinical Outcomes After Switching from Remicade ${ }^{\circledR}$ to Biosimilar CT-P13 in Inflammatory Bowel Disease. Dig. Dis. Sci. 2017, 62, 3117-3122. [CrossRef] [PubMed]

39. Smits, L.J.T.; Derikx, L.A.A.P.; de Jong, D.J.; de Jong, D.J.; van Esch, A.A.J.; Boshuizen, R.S.; Drenth, J.P.H.; Hoentjen, F. Clinical outcomes following a switch from Remicade ${ }^{\circledR}$ to the biosimilar CT-P13 in inflammatory bowel disease patients: A prospective observational cohort study. J Crohn's Colitis 2016, 10, 1287-1293. [CrossRef]

40. Ben-Horin, S.; Vande Casteele, N.; Schreiber, S.; Lakatos, P.L. Biosimilars in Inflammatory Bowel Disease: Facts and Fears of Extrapolation. Clin. Gastroenterol. Hepatol. 2016, 14, 1685-1696. [CrossRef]

41. Feagan, B.G.; Choquette, D.; Ghosh, S.; Gladman, D.D.; Ho, V.; Meibohm, B.; Zou, G.; Xu, Z.; Shankar, G.; Sealey, D.C.; et al. The challenge of indication extrapolation for infliximab biosimilars. Biologicals 2014, 42, 177-183. [CrossRef] [PubMed]

42. Lee, H. Is extrapolation of the safety and efficacy data in one indication to another appropriate for biosimilars? AAPS J. 2014, 16, 22-26. [CrossRef]

43. Strand, V.; Balsa, A.; Al-Saleh, J.; Barile-Fabris, L.; Horiuchi, T.; Takeuchi, T.; Lula, S.; Hawes, C.; Kola, B.; Marshall, L. Immunogenicity of Biologics in Chronic Inflammatory Diseases: A Systematic Review. BioDrugs 2017, 31, 299-316. [CrossRef]

44. Hung, A.; Vu, Q.; Mostovoy, L. A Systematic Review of U.S. Biosimilar Approvals: What evidence does the FDA require and how are manufacturers responding? J. Manag. Care Spec. Pharm. 2017, 23, 1234-1244b. [CrossRef] [PubMed]

45. Razanskaite, V.; Bettey, M.; Downey, L.; Wright, J.; Callaghan, J.; Rush, M.; Whiteoak, S.; Ker, S.; Perry, K.; Underhill, C.; et al. Biosimilar Infliximab in Inflammatory Bowel Disease: Outcomes of a Managed Switching Programme. J. Crohn's Colitis 2017, 11, 690-696. [CrossRef] [PubMed]

46. Zhai, M.Z.; Sarpatwari, A.; Kesselheim, A.S. Why are biosimilars not living up to their promise in the US? AMA J. Ethics 2019, 21, 668-678. [CrossRef]

47. Chambers, J.D.; Lai, R.C.; Margaretos, N.M.; Panzer, A.D.; Cohen, J.T.; Neumann, P.J. Coverage for Biosimilars vs Reference Products among US Commercial Health Plans. JAMA J. Am. Med. Assoc. 2020, 323, 1972-1973. [CrossRef]

48. Home I Biosimilars Council I Leading Resource on Biosimilars. Available online: https://biosimilarscouncil.org/ (accessed on 1 May 2021).

49. Hindryckx, P.; Vande Casteele, N.; Novak, G.; Khanna, R.; D’Haens, G.; Sandborn, W.J.; Danese, S.; Jairath, V.; Feagan, B.G. The expanding therapeutic armamentarium for inflammatory bowel disease: How to choose the right drug[s] for our patients? J. Crohn's Colitis 2018, 12, 105-109. [CrossRef]

50. Misselwitz, B.; Juillerat, P.; Sulz, M.C.; Siegmund, B.; Brand, S. Emerging Treatment Options in Inflammatory Bowel Disease: Janus Kinases, Stem Cells, and More. Digestion 2020, 101, 69-82. [CrossRef]

51. Monteleone, G.; Neurath, M.F.; Ardizzone, S.; Di Sabatino, A.; Fantini, M.C.; Castiglione, F.; Scribano, M.L.; Armuzzi, A.; Caprioli, F.; Sturniolo, G.C.; et al. Mongersen, an Oral SMAD7 Antisense Oligonucleotide, and Crohn's Disease. N. Engl. J. Med. 2015, 372, 1104-1113. [CrossRef]

52. Shukla, T.; Sands, B.E. Novel Non-biologic Targets for Inflammatory Bowel Disease. Curr. Gastroenterol. Rep. 2019, $23,21-22$. [CrossRef]

53. Felice, C.; Lewis, A.; Armuzzi, A.; Lindsay, J.O.; Silver, A. Review article: Selective histone deacetylase isoforms as potential therapeutic targets in inflammatory bowel diseases. Aliment. Pharm. Ther. 2015, 41, 26-38. [CrossRef]

54. Cao, F.; Zwinderman, M.R.H.; Dekker, F.J. The process and strategy for developing selective histone deacetylase 3 inhibitors. Molecules 2018, 23, 551. [CrossRef]

55. Zhang, L.; Chen, Y.; Jiang, Q.; Song, W.; Zhang, L. Therapeutic potential of selective histone deacetylase 3 inhibition. Eur. J. Med. Chem. 2019, 162, 534-542. [CrossRef]

56. Karner, M.; Kocjan, A.; Stein, J.; Schreiber, S.; Von Boyen, G.; Uebel, P.; Schmidt, C.; Kupcinskas, L.; Dina, I.; Zuelch, F.; et al. First multicenter study of modified release phosphatidylcholine LT-02 in ulcerative colitis: A randomized, placebo-controlled trial in mesalazine-refractory courses. Am. J. Gastroenterol. 2014, 109, 1041-1051. [CrossRef] [PubMed]

57. Chang, S.; Hanauer, S. Optimizing pharmacologic management of inflammatory bowel disease. Expert Rev. Clin. Pharmacol. 2017, 10, 595-607. [CrossRef] [PubMed]

58. Judge, C.; Saeidi, R.; Sugrue, K.; Rabbitt, L.; Keogh, A.; Byron, C.; Zulquernain, S.A.; Gleeson, S.; O’Toole, A.; Buckley, M.; et al. Combining Therapies in Inflammatory Bowel Disease: End of the Line or a New Era? Inflamm. Bowel Dis. 2021, 27, 956-959. [CrossRef] [PubMed]

59. Hilley, P.; Gilmore, R.; Srinivasan, A.; Choy, M.; De Cruz, P. Combined Targeted Treatment Using Biologic-Tofacitinib Co-Therapy in Chronic Active Ulcerative Colitis. Inflamm. Bowel Dis. 2021. [CrossRef]

60. Sardesai, A.; Dignass, A.; Quon, P.; Milev, S.; Cappelleri, J.C.; Kisser, A.; Modesto, I.; Sharma, P.P. Cost-effectiveness of tofacitinib compared with infliximab, adalimumab, golimumab, vedolizumab and ustekinumab for the treatment of moderate to severe ulcerative colitis in Germany. J. Med. Econ. 2021, 24, 279-290. [CrossRef]

61. Home Page I XELJANZ®(tofacitinib) I Safety Info. Available online: https://www.xeljanz.com/ (accessed on 1 May 2021). 
62. Fouladi, M.; Park, J.R.; Stewart, C.F.; Gilbertson, R.J.; Schaiquevich, P.; Sun, J.; Reid, J.M.; Ames, M.M.; Speights, R.; Ingle, A.M.; et al. Pediatric phase I trial and pharmacokinetic study of vorinostat: A Children's Oncology Group phase I consortium report. J. Clin. Oncol. 2010, 28, 3623-3629. [CrossRef]

63. Häuser, W.; Moser, G.; Klose, P.; Mikocka-Walus, A. Psychosocial issues in evidence-based guidelines on inflammatory bowel diseases: A review. World J. Gastroenterol. 2014, 20, 3663-3671. [CrossRef]

64. Wang, S.L.; Shao, B.Z.; Zhao, S.B.; Chang, X.; Wang, P.; Miao, C.Y.; Li, Z.S.; Bai, Y. Intestinal autophagy links psychosocial stress with gut microbiota to promote inflammatory bowel disease. Cell Death Dis. 2019, 10, 6. [CrossRef]

65. Sweeney, L.; Moss-Morris, R.; Czuber-Dochan, W.; Meade, L.; Chumbley, G.; Norton, C. Systematic review: Psychosocial factors associated with pain in inflammatory bowel disease. Aliment. Pharmacol. Ther. 2018, 47, 715-729. [CrossRef]

66. Blaney, C.; Sommer, J.; El-Gabalawy, R.; Bernstein, C.; Walld, R.; Hitchon, C.; Bolton, J.; Sareen, J.; Patten, S.; Singer, A.; et al. CIHR Team in Defining the Burden and Managing the Impact of Psychiatric Comorbidity in Immune-Mediated Inflammatory Disease. Incidence and temporal trends of co-occurring personality disorder diagnoses in immune-mediated inflammatory diseases. Epidemiol. Psychiatr. Sci. 2020, 29. [CrossRef]

67. Marrie, R.A.; Walld, R.; Bolton, J.M.; Sareen, J.; Walker, J.R.; Patten, S.B.; Singer, A.; Lix, L.M.; Hitchon, C.A.; El-Gabalawy, R.; et al. CIHR Team in Defining the Burden and Managing the Effects of Psychiatric Comorbidity in Chronic Immunoinflammatory Disease. Increased incidence of psychiatric disorders in immune-mediated inflammatory disease. J. Psychosom. Res. 2017, 101, 17-23. [CrossRef] [PubMed]

68. Marrie, R.A.; Walld, R.; Bolton, J.M.; Sareen, J.; Walker, J.R.; Patten, S.B.; Singer, A.; Lix, L.M.; Hitchon, C.A.; El-Gabalawy, R.; et al. CIHR Team in Defining the Burden and Managing the Effects of Psychiatric Comorbidity in Chronic Immunoinflammatory Disease. Rising incidence of psychiatric disorders before diagnosis of immune-mediated inflammatory disease. Epidemiol. Psychiatr. Sci. 2019, 28, 333-342. [CrossRef] [PubMed]

69. Halloran, J.; McDermott, B.; Ewais, T.; Begun, J.; Karatela, S.; D’Emden, H.; Corias, C.; Denny, S. The psychosocial burden of inflammatory bowel disease in adolescents and young adults. Int. Med. J. 2020. [CrossRef] [PubMed]

70. Weaver, E.; Szigethy, E. Managing Pain and Psychosocial Care in IBD: A Primer for the Practicing Gastroenterologist. Curr. Gastroenterol. Rep. 2020, 22, 4. [CrossRef]

71. Pineles, D.; Malter, L.; Liang, P.S.; Arsuaga, A.; Bosworth, B.; Hudesman, D.P.; Chang, S. The nocebo effect and patient perceptions of biosimilars in inflammatory bowel disease. Eur. J. Clin. Pharmacol. 2018, 74, 1361-1362. [CrossRef]

72. Kristensen, L.E.; Alten, R.; Puig, L.; Philipp, S.; Kvien, T.K.; Mangues, M.A.; van den Hoogen, F.; Pavelka, K.; Vulto, A.G. Non-pharmacological Effects in Switching Medication: The Nocebo Effect in Switching from Originator to Biosimilar Agent. BioDrugs 2018, 32, 397-404. [CrossRef]

73. D'Amico, F.; Pouillon, L.; Argollo, M.; Hart, A.; Fiorino, G.; Vegni, E.; Radice, S.; Gilardi, D.; Fazio, M.; Leone, S.; et al. Multidisciplinary management of the nocebo effect in biosimilar-treated IBD patients: Results of a workshop from the NOCE-BIO consensus group. Dig. Liver Dis. 2020, 52, 138-142. [CrossRef]

74. Pouillon, L.; Danese, S.; Hart, A.; Fiorino, G.; Argollo, M.; Selmi, C.; Carlo-Stella, C.; Loeuille, D.; Costanzo, A.; Lopez, A.; et al. Consensus report: Clinical recommendations for the prevention and management of the nocebo effect in biosimilar-treated IBD patients. Aliment. Pharmacol. Ther. 2019, 49, 1181-1187. [CrossRef]

75. Queiroz, N.S.F.; Saad-Hossne, R.; de Fróes, R.S.B.; Penna, F.G.C.E.; Gabriel, S.B.; Martins, A.L.; Teixeira, F.V. Discontinuation rates following a switch from a reference to a biosimilar biologic in patients with inflammatory bowel disease: A systematic review and meta-analysis. Arq. Gastroenterol. 2020, 57, 232-243. [CrossRef]

76. Bernard, E.J.; Fedorak, R.N.; Jairath, V. Systematic Review: Non-medical Switching of Infliximab to CT-P13 in Inflammatory Bowel Disease. Dig. Dis. Sci. 2020, 65, 2354-2372. [CrossRef]

77. Socal, M.P.; Garrett, J.B.; Tayler, W.B.; Bai, G.; Anderson, G.F. Naming Convention, Interchangeability, and Patient Interest in Biosimilars. Diabetes Spectr. 2020, 33, 273-279. [CrossRef] [PubMed]

78. Kolho, K.L. Therapeutic Drug Monitoring and Outcome of Infliximab Therapy in Pediatric Onset Inflammatory Bowel Disease. Front. Pediatr. 2021, 13, 623689. [CrossRef] [PubMed]

79. Kang, B.; Lee, Y.; Lee, K.; Choi, Y.O.; Choe, Y.H. Long-term outcomes after switching to CT-P13 in pediatric-onset inflammatory bowel disease: A single-center prospective observational study. Inflamm. Bowel Dis. 2018, 24, 607-616. [CrossRef] [PubMed]

80. Sieczkowska, J.; Jarzębicka, D.; Banaszkiewicz, A.; Plocek, A.; Gawronska, A.; Toporowska-Kowalska, E.; Oracz, G.; Meglicka, M.; Kierkus, J. Switching Between Infliximab Originator and Biosimilar in Paediatric Patients with Inflammatory Bowel Disease. Preliminary Observations. J Crohn's Colitis 2016, 10, 127-132. [CrossRef] [PubMed]

81. Kansen, H.M.; Van Rheenen, P.F.; Houwen, R.H.J.; Tjon, A.; Ten, W.; Damen, G.M.; Kindermann, A.; Escher, J.C.; Wolters, V.M. Kids with Crohn's, Colitis (KiCC) Working Group for Collaborative Paediatric IBD Research in the Netherlands. Less Anti-infliximab Antibody Formation in Paediatric Crohn Patients on Concomitant Immunomodulators. J. Pediatr. Gastroenterol. Nutr. 2017, 65, 425-429. [CrossRef]

82. Wong, K.; Isaac, D.M.; Wine, E. Growth Delay in Inflammatory Bowel Diseases: Significance, Causes, and Management. Dig. Dis. Sci. 2021, 66, 954-964. [CrossRef]

83. Jin, H.Y.; Lim, J.S.; Lee, Y.; Choi, Y.; Oh, S.H.; Kim, K.M.; Yoo, H.W.; Choi, J.H. Growth, puberty, and bone health in children and adolescents with inflammatory bowel disease. BMC Pediatr. 2021, 21, 1. [CrossRef] 
84. Sakka, S.D.; Cheung, M.S. Management of primary and secondary osteoporosis in children. Ther. Adv. Musculoskelet Dis. 2020, 12. [CrossRef]

85. Ward, L.M.; Konji, V.N.; Ma, J. The management of osteoporosis in children. Osteoporos Int. 2016, 27, 2147-2179. [CrossRef] 